\title{
Kanser hücreleri üzerine Origanum Minutiflorum'un Sitotoksik Etkisinin Araştırılması
}

\author{
Oktay Özkan ${ }^{*}$, Caner Özbey ${ }^{2}$, Işıl Aydemir ${ }^{3}$, İsmail Sarı ${ }^{4}$, Gonca Dönmez ${ }^{5}$, Fatma Esin Kırık ${ }^{6}$, Ahmet Savran ${ }^{7}$, \\ Mehmet İbrahim Tuğlu 8
}

${ }^{1}$ Niğde Ömer Halisdemir Üniversitesi, Tıp Fakültesi, Tıbbi Farmakoloji Anabilim Dalı, Niğde, Türkiye

${ }^{2}$ Niğde Ömer Halisdemir Üniversitesi, Tıp Fakültesi, Tıbbi Patoloji Anabilim Dalı Niğde, Türkiye

${ }^{3}$ Niğde Ömer Halisdemir Üniversitesi, Tıp Fakültesi, Tıp Fakültesi, Histoloji ve Embriyoloji Anabilim Dalı Niğde, Türkiye

${ }^{4}$ Niğde Ömer Halisdemir Üniversitesi, Tıp Fakültesi, Tıbbi Biyokimya Anabilim Dalı Niğde, Türkiye

${ }^{5}$ Niğde Ömer Halisdemir Üniversitesi, Tıp Fakültesi, Tıbbi Biyoloji Anabilim Dalı, Niğde, Türkiye Niğde

${ }^{6}$ Ömer Halisdemir Üniversitesi, Tıp Fakültesi, Tıbbi Mikrobiyoloji Anabilim Dalı Niğde, Türkiye

${ }^{7}$ Niğde Ömer Halisdemir Üniversitesi, Fen Edebiyat Fakültesi, Biyoloji Bölümü, Botanik Anabilim Dalı Niğde, Türkiye

${ }^{8}$ Manisa Celal Bayar Üniversitesi, Tıp Fakültesi, Histoloji ve Embriyoloji Anabilim Dalı, Manisa Türkiye oktay.ozkan@ohu.edu.tr, canerozbey@ohu.edu.tr, isil_aydemir@yahoo.com,isari@ohu.edu.tr, gdonmez@ohu.edu.tr, fatmaesinkirik@ohu.edu.tr, asavran@ohu.edu.tr, mituglu@yahoo.com

Orcid:0000-0002-9794-8863

Orcid:0000-0002-5001-5150

Orcid:0000-0002-4143-7319

Orcid:0000-0003-3732-2102

Orcid:0000-0001-7778-0998

Orcid:0000-0001-6677-0233

Orcid:0000-0003-4609-9547

Orcid:0000-0002-0569-8415

*Sorumlu Yazar / Corresponding Author: Oktay Özkan

Gönderim Tarihi / Received:13.03.2018

Kabul Tarihi / Accepted: 19.06.2019

DOI: $10.34087 /$ cbusbed.405472

\footnotetext{
$\ddot{O} \mathbf{z}$

Amaç: Kanser, doku ve organları istila eden ve vücudun diğer kısımlarına sıçrayabilen, hücrelerin anormal gelişimidir. Meme kanseri en çok tekrarlanan tanıya sahip ve dünya genelinde kadınlarda kanserle ilişkili ölümlerde en önde gelen sebeplerdendir. Tıbbi bitkiler bazı kanser türlerinde antikarsinojenik özelliklere sahip olabilmektedir. Bu çalışmanın amacı Origanum minutiflorum O. Schwarz \& P.H. Davis'in in vitro şartlarda, meme kanseri hücre dizilerinde sitotoksik etkisini araştırmaktır.

Gereç ve Yöntem: Bu çalışmada, MDA-MB-231 ve MCF-7 meme kanseri hücre dizileri ve adipoz dokudan izole edilmiş mezenkimal kök hücreleri kullanıldı. Origanum minutiflorum'dan elde edilmiş esansiyel yağa maruz bırakılmış tüm hücre dizilerinde MTT testi aracılığıyla $\mathrm{IC}_{50}$ dozu hesaplandı. Her bir hücre dizisinin $\mathrm{IC}_{50}$ dozunda eNOS, p53, PCNA ve TUNEL için immunositokimya boyaması yapıldı. Sonuçlar Graphpad yazılımı kullanılarak one-way-ANOVA kullanılarak değerlendirildi.

Bulgular: Meme kanseri hücrelerinin proliferasyonu oregano yağı tarafından inhibe edildi. Oregano yağı mezenkimal kök hücrelerinde herhangi bir sitotoksik etki göstermedi. eNOS ve p53 ile apoptozisin göstergesi TUNEL'de artış yoluyla oregano yağının kanser hücrelerinde sitotoksik olduğu ortaya çıktı ve PCNA boyamada proliferasyonun azaldığı tespit edildi.

Sonuç: Bizim verilerimize göre oregano yağı MDA-MB-231 ve MCF-7 meme kanseri hücrelerinde sitotoksik bir etkiye sahiptir ve diğer biyolojik aktiviteleri için aktif komponentlerini tanımlayacak testlere ihtiyaç vardır.

Anahtar Kelimeler: Meme Kanseri, MCF-7, MDA-MB-231, Origanum Minutiflorum, Sitotoksisite, Oksidatif Stres, Apoptozis.
} 


\begin{abstract}
Objective: Cancer is defined by a abnormal growth of cells, that invade tissues and organs and spread to other parts of the body. Breast cancer is one of the most repeatedly diagnosed cancers and the foremost cause of death among women worldwide. Medicinal plants can have an anticarcinogenic effect in some cancer types. Our aim is to search the cytotoxic effect of Origanum minutiflorum O. Schwarz \& P.H. Davis on breast cancer cells in vitro conditions.

Methods: In this study, MDA-MB-231 and MCF-7 breast cancer cell lines and adipose tissue derived mesenchymal stem cells were used. Essential oil from Origanum minutiflorum was exposed to the all cells and $\mathrm{IC}_{50}$ dose was calculated by MTT assay. We have examined immunocytochemical staining of eNOS, p53, PCNA and TUNEL at $\mathrm{IC}_{50}$ dose for each cells. The results were evaluated using one-way-ANOVA by Graphpad software.

Results: The proliferation of breast cancer cells were inhibited by oregano oil. Oregano oil did not show any cytotoxic effect in mesenchymal stem cells. It was determined that cytotoxic effect of oregano oil on cancer cells was occurred through increase of eNOS and p53 staining for survival and the TUNEL labeling for apoptosis, and decreased of PCNA staining for proliferation.

Conclusion: According to our data, oregano oil has cytotoxic effect on MDA-MB-231 and MCF-7 breast cancer cell lines, and it needs to be analysis to detect active components for other biological activities.
\end{abstract}

Keywords:Breast Cancer, MCF-7; MDA-MB-231, Origanum Minutiflorum, Cytotoxicity, Oxidative Stress, Apoptosis.

\section{Giriş}

Meme kanseri, hem gelişmiş hem de gelişmekte olan ülkelerdeki kadınlar arasında konulan kanser tanıları ve kanserle ilişkili ölümler arasında en sık rastlanandır [1]. $\mathrm{Bu}$ kanser türü kadınlarda görülen kanser vakalarının $\% 25$ 'inden ve kansere bağlı ölümlerin \%15'inden sorumludur [2]. Meme kanserleri tipik olarak östrojen reseptörleri, progesteron reseptörleri ve insan epidermal büyüme faktörü reseptörlerinin ekspresyonuna göre sinıflandırılırlar ki bu durum hastalığın tedavisi, cevapları ve sonuçlar için oldukça önemlidir $[3,4]$. Meme kanserlerinin tedavisinde genel olarak bazen adjuvan kemoterapi veya hormon tedavisi ile desteklenen cerrahi ve radyasyon terapisi uygulanır [1]. Fakat bu konvansiyonel tedaviler kanıtlanmış yan etkileri nedeniyle tatmin edici değildir [5]. Kanser tedavisinde son zamanlardaki gelişmelere rağmen yeni alternatif ilaçlara olan ihtiyaç devam etmektedir [6].

Yüksek morbidite ve mortalite oranına sahip olduğu için, meme kanserinin tedavisinde etkili bir ilacın gerekliliği açıktır ve daha az toksik ve daha etkili kemoterapötik ajanların bulunması ve geliştirilmesi meme kanserinde potansiyel bir tedavi yaklaşımı bakımından oldukça önemlidir $[7,8]$. Bu amaçla in vivo veya in vitro meme kanser modellerinde birçok hücre dizini kullanılmaktadır. İn vitro çalışmalarda kullanılan MCF-10A, MCF-7, SK-BR-3, MDA-MB-231, MDAMB-436 ve 4T1 hücre dizinleri bunlardan bazılarıdır [913]. $\mathrm{Bu}$ hücre dizinleri meme dokusu kaynaklı adenokarsinom olup östrojen reseptörleri açısından farkl11lk göstermektedirler. MCF-7, ilk kez 1970 yılında meme kanseri akciğerine metastaz yapan kadın hastadan izole edilmiştir. Östrojen reseptör (ER) pozitif olduğundan, metastaz özelliği taşımaktadır [14-16]. Bir diğer meme kanseri dizin hücresi MDA-MB-231 ise ER(-) olup metastaz ve in vivo kanser modeli çalışmaları için uygun bir hücre dizinidir [17-19]. MCF7 hücre dizininde olduğu gibi, MDA-MB-231 hücreleri de in vitro şartlarda yapışma özelliği (adherent) gösterdiğinden in vitro deneyler için çoğunlukla bu hücreler seçilmektedir [14,19].
Yaklaşık olarak 300-500 bin bitki türünden sadece $\% 15$ 'i fitokimyasal özellikleri bakımından, \%6's1 da farmakolojik özellikleri bakımından çalışılmıştır. İçlerinde antikanser potansiyelde olan çoğu bitki kökenli ilacın henüz keşfedilmediğine inanılmaktadır [20].

Aromatik tıbbi bitkilerden elde edilen farklı esansiyel yağların çeşitli insan tümörleri ve tümör hücre hatlarında kemoprotektif potansiyele sahip oldukları belirlenmiştir [21]. Tıbbi bitkilerin kanser gibi hastalıklara karşı koruyucu ve sitotoksik etkileri içerdikleri fitokimyasal bileşiklerle alakalıdır [22].

Oregano türleri esansiyel yağları tıbbi, koruyucu ve ticari öneme sahiptirler [23]. Bu esansiyel yağda en yüksek konsantrasyonda bulunan bileşik karvakrol olup özellikle biyoaktif özellikleri ile de ön plana çıkmaktadır [23,24]. Karvakrolun tanımlanan etkinlikleri arasında antibakteriyel, antioksidan, insektisidal, antikarsinojenik aktivite, antispazmodik etki, asetilkolinesteraz inhibisyonu, lipid peroksidaz inhibisyonu, radikal bileşik süpürücü etki, makrofaj stimülantı ve kardiyak depresan aktivite bulunmaktadır. Oregano esansiyel yağının etkinlik derecesi ile içerdiği fenolik bileşikler arasında kuvvetli bir ilişki vardır [23]. Esansiyel yağ içeriği ve biyoaktivitesi ise origanum türüne, yetiştiği coğrafyaya ve klimatik şartlara göre değişiklikler göstermektedir $[25,26]$.

'Sütçüler kekiği' veya 'Tota kekiği' olarak da bilinen Origanum minutiflorum O. Schwarz et. H. Davis ülkemizde sadece Isparta ilinin Sütçüler yöresinde yayılış gösteren endemik bir türdür [27]. Ancak bu endemik türün tıbbi etkinlikleri ile ilgili yeterince araştırma yapılmamıştır ve antikanserojen etkinliği hakkında yeterli bilgi bulunmamaktadır.

$\mathrm{Bu}$ çalışmada; Origanum minutiflorum esansiyel yağının in vitro şartlarda, hormon reseptörlerini taşıması açısından farklı iki meme kanseri hücre dizinleri olan MDA-MB-231 (ER-) ve MCF-7 (ER+) hücrelerinde ve 
kontrol olarak mezenkimal kök hücrelerdeki sitotoksik etkinliği incelendi.

\section{Gereç ve Yöntem \\ Bitkisel Materyal ve Esansiyel Yağ Ekstraksiyonu}

Origanum minutiflorum bitki numuneleri Isparta ili Sütçüler ilçesi dağlık kesiminden 2015 y1lı Temmuz ayında taze olarak toplandı. Tür tanımlaması yapıldıktan sonra oda isısında ve karanlıkta 15 gün süreyle kurumaya bırakıldı. Kurumuş bitki numunelerinin yaprakları ayrilarak toz haline getirildi. Yapraklara, 100 gr / $500 \mathrm{ml}$ su ile clevenger aparatında hidrodistilasyon uygulanarak esansiyel yağ elde edildi. Esansiyel yağ eldesi \%4.2 olarak tespit edildi.

\section{Hücre Kültürü}

İnsan meme kanseri hücre dizinleri MCF-7 (ACC-115, Deutsche Sammlung von Mikroorganismen und Zellkulturen, Braunschweig, Germany) ve MDA-MB231 (ACC-732, Deutsche Sammlung von Mikroorganismen und Zellkulturen, Braunschweig, Germany), \% 10 fetal sığır serumu (FBS, S0113, Biochrom, Berlin Germany) 200 mM L-glutamin (K0283, Biochrom, Berlin Germany) ve $100 \mathrm{IU} / \mathrm{ml}$ penisilin/streptomicin (A2213, Biochrom, Berlin Germany) içeren RPMI-1640 (F1213, Biochrom, Berlin Germany) besiyeri içerisinde $37^{\circ} \mathrm{C}$ sicaklık ve $\% 5 \mathrm{CO}_{2}$ sağlayan inkübatörde kültüre edildi. Deneyimizde kontrol grubunda normal stromal hücreler olarak yağ doku kaynaklı mezenkimal kök hücre (YDMKH) kullanıldı. YDMKH'ler önceki bir çalışmada izole edilip $-80^{\circ} \mathrm{C}$ 'de saklanmıștır (Etik onayı no: 77.637.43532, Kabul tarihi: 17/09/2014; Manisa Celal Bayar Üniversitesi Hayvan Deneyleri Yerel Etik Kurulu). $80^{\circ} \mathrm{C}$ 'de saklanmış olan YDMKH'ler $37^{\circ} \mathrm{C}$ 'deki su banyosunda çözdürülerek $10 \%$ fetal sığır serumu (S0113, Biochrom, Berlin, Germany), $50 \mu \mathrm{g} / \mathrm{ml}$ gentamisin (A2712, Biochrom, Berlin, Germany), 100 $\mathrm{UI} / \mathrm{ml}$. penisilin/streptomicin ve $200 \mathrm{mM}$ L-glutamin içeren alfa-MEM (F0915, Biochrom, Berlin Germany) besiyerinde kültüre edilerek çoğaltıldı. Tüm hücrelerin besiyerleri iki günde bir değiştirilerek hücrelerin yaklaşık \%70-80 konfluensiye ulaşmaları sağlandı $[28,29]$.

\section{Sitotoksisite Testi}

Oregano yağının $\mathrm{IC}_{50}$ dozunu belirlemek amacıyla 3(4,5-dimethylthiazol-2-y1)-2,5-diphenyltetrazolium bromide (MTT, M6494, Invitrogen) metodu kullanıldı. $\mathrm{Bu}$ amaçla hücrelerin her biri 96 kuyucuklu kültür kaplarına $\left(2.5 \times 10^{5}\right.$ hücre/kuyucuk $)$ ekildi ve 24 saat süreyle konfluent olmaları sağlandı. Hücreler farklı konsantrasyonlardaki Oregano yaği $(0,1 / 10,1 / 50$, $1 / 100,1 / 1000 \mathrm{v} / \mathrm{v})$ ile 24 saat muamele edildi. Süre sonunda Oregano yağı içeren besiyeri çekilerek ortamdan uzaklaştırıldı ve $100 \mu \mathrm{L}$ taze besiyeri ile birlikte $10 \mu \mathrm{L}$ MTT $(5 \mathrm{mg} / \mathrm{ml}$ distile su) hücrelere eklendi. Hücreler MTT ile $37^{\circ} \mathrm{C}$ 'de 4 saat inkübe edildi. İnkübasyondan sonra MTT içeren besiyeri çekilerek atıldı ve her bir kuyucuğa $100 \mu \mathrm{L}$ dimetil sulfoksit (DMSO, A3672, AppliChem, Darmstadt, Germany) konuldu ve multiplaka okuyucu UV spektrofotometrede
570 nm'de absorbans ölçüldü. Absorbans sonuçlarına göre Oregano yağının her bir hücre tipi için $\mathrm{IC}_{50}$ dozları hesapland1 [30].

\section{Esansiyel yağ uygulaması}

Tüm hücreler 8 kuyucuklu hücre kültür kaplarına $\left(2.5 \times 10^{5}\right.$ hücre/kuyucuk) ekildi ve inkübe edilerek konfluent olmaları sağlandı. Her bir hücre, kontrol (uygulama yapılmadi) ve deney grubu $\left(\mathrm{IC}_{50}\right.$ dozunda Oregano yağı uygulandı) olarak iki gruba ayrıldı. Sitotoksisite testi sonrası IC50 dozları YDMKH için 40,5 $\mu \mathrm{L} / \mathrm{ml}$, MCF-7 için 11,5 $\mu \mathrm{L} / \mathrm{ml}$ ve MDA-MB-231 için $14,5 \mu \mathrm{L} / \mathrm{ml}$ olarak hesapland. Hücreler, $\mathrm{IC}_{50}$ dozundaki Oregano yağı ile 24 saat muamele edildikten sonra immünositokimya ve TUNEL metodları ile boyand1.

\section{İmmünositokimya}

Hücreler, deney sonrasında bitki eksraktı içeren besiyeri çekilip atıldı ve PBS (Phosphate buffer saline) 'de hazırlanmış \%4'lük paraformaldehid solüsyonu $(\mathrm{pH} 7,4)$ ile fikse edildikten sonra 3 defa 5'er dk PBS ile yıkandi. \%0,1'lik Triton-X100 (A4975, AppliChem, Darmstadt, Germany) solüsyonu ile $15 \mathrm{dk}$ inkübe edildikten sonra tekrar PBS ile yıkama işlemi yapılıp ve $\% 3$ hidrojen peroksit (H2O2, 1 08600, Merck, Darmstadt, Germany) ile $30 \mathrm{dk}$ bekletilerek endojen peroksidaz aktivitesi inhibe edildi. 1 saat bloklama serumu ile inkübe edilen hücreler yıkanmadan sadece serumun alınmasından sonra primer antikorları anti-endotelyal nitrik oksit sentaz (eNOS, sc-654, Santa Cruz Biotechnology), antip53 (bs-0033R, Massachusetts, USA) ve antiproliferating cell nuclear antigen (PCNA, orb11245, Biorbyt) ile 18 saat inkübe edildi. Yıkama işleminden sonra "biotinlenmiş anti-mouse/anti-rabbit" konjuge edilmiş streptavidin-horsedish peroksidaz solüsyonları (Histostain kit, 85-9043, Zymed, Carlsbad, USA) ile 30 'ar dk boyand. Her bir ikincil antikor 3 defa 5 'er $\mathrm{dk}$ PBS ile yıkandı. İmmunreaktiviteleri görünür halde saptamak amaciyla diaminobenzidin (DAB, 00-2014, İnvitrogen, CA, USA) ile $5 \mathrm{dk}$ boyama yapıldı. Primer antikorun yerine PBS konarak negatif kontrolleri yapıldı. Distile su ile yıkama işleminden sonra Mayer's hematoksilen (800-729-8350, ScyTek, UT, USA) ile artalan boyamanın ardından distile su ile $10 \mathrm{dk}$ yıkanan hücreler kapatma medyumu (K002, DBS, Pleasanton, USA) ile kapatıldı. Kör yöntemle boyama sonuçları 1 şık mikroskop (BX43, Olympus, Japan) altında incelendi [31].

\section{Apoptozun belirlenmesi}

Apoptozu belirlemek amaciyla terminal transferase dUTP Nick End Labeling (TUNEL, S7101, Millipore, Billerica, MA, USA) yöntemi kullanıldı. Süre sonunda hücreler PBS (Phosphate buffer saline) 'de hazırlanmış $\% 4$ 'lük paraformaldehid solüsyonu $(\mathrm{pH} \mathrm{7,4)}$ ile fikse edildikten sonra 3 defa 5'er dk PBS ile y1kandı. $\% 0,1$ 'lik Triton-X100 solüsyonu ile $15 \mathrm{dk}$ inkübe edildikten sonra tekrar PBS ile yıkama işlemi yapılıp ve $\% 3$ hidrojen peroksit $(\mathrm{H} 2 \mathrm{O} 2)$ ile $30 \mathrm{dk}$ bekletilerek endojen peroksidaz aktivitesi inhibe edildi. Hücreler 5 dk. Equilibration buffer ile oda isisinda tutulduktan sonra TdT-enzimi ile nemli atmosferik ortamda $37^{\circ} \mathrm{C}$ de 
$60 \mathrm{dk}$. bekletildi. Sürenin ardından Stop Wash Buffer ile $10 \mathrm{dk}$. bekletildikten sonra Antidioksigenin Peroksidaz Konjugatı ile $30 \mathrm{dk}$. muamele edilen hücreler 5'er dakika 3 kez PBS ile yıkand. Ardından DAB (Diaminobenzidin) ile boyama yapıldı ve artalan boyaması Mayer's hematoksileni ile gerçekleştirildi.

Kör yöntemle 1şık mikroskobu altında TUNEL pozitif hücreler saptanarak apoptotik indeks hesaplandı ve ortalamalar istatiksel olarak değerlendirildi [32].

\section{İstatiksel analiz}

Çalışmamızda kullanılan tüm analizler üç kez tekrarlandı. İmmunositokimyasal boyamalar incelenerek zayıf $(+)$, orta $(++)$ ve şiddetli $(+++)$ olarak belirlendi. Boyanan hücre miktarı H-skor yöntemiyle hesaplandı ve veriler istatiksel olarak analiz edildi. H-skor incelemesinde boyanma oranı her alanda pozitif işaretli hücre sayısının oranı belirlenerek boyanma şiddeti ile değerlendirildi. $\mathrm{Bu}$ amaçla "(1+boyanma şiddeti/3) x boyanma oranı" formülü kullanıldı. Bulgular GraphPad (San Diego, CA, USA) programı aracılığı ile tek yönlü ANOVA, Tukey-Kramer çoklu karşılaştırma testi ile analiz edildi. Sonuçlar, $\mathrm{p}<0.05$ için anlamlı kabul edildi $[33,34]$.

\section{Bulgular}

Oregano yağının in vitro ortamda meme kanseri hücreleri üzerine sitotoksik etkisi MTT testi ile analiz edildi. Her bir hücre için IC50 dozu istatistik programı kullanılarak (GraphPad) hesaplandı. IC50 dozları YDMKH için 40,5 $\mu \mathrm{L} / \mathrm{ml}$, MCF-7 için $11,5 \mu \mathrm{L} / \mathrm{ml}$ ve MDA-MB-231 için 14,5 $\mu \mathrm{L} / \mathrm{ml}$ olarak bulundu.

IC50 dozlar1 uygulanarak yapılan immünositokimya boyaması sonrası görüntüler alınarak incelendiğinde oksidatif stres belirteci eNOS dağılımının tüm örneklerde var olduğu; ancak özellikle meme kanseri hücrelerindeki boyanmanın YDMKH'lere göre anlamlı (***P<0.001) şekilde arttığ 1 görüldü (Şekil 1 ve 2).

Apoptoz açısından bakıldığında p53 immünoreaktivitesinin, oregano yağ uygulamasiyla kontrol grubuna göre artarken, hücre çoğalma belirteci PCNA boyanmasının azaldığı izlendi (Şekil 3 ve 4).

İmmünositokimyasal boyanma sonuçları ile uyumlu olarak TUNEL pozitif hücre sayısının meme kanser hücrelerinde YDMKH'lere göre anlamlı $(* * * \mathrm{P}<0.001)$ artış olduğu saptandı (Şekil 5 ve 6). MCF-7 ve MDAMB-231 hücrelerindeki boyanmalar karşılaştırıldı ğında, apoptotik hücre sayısının MCF-7 hücrelerinde daha fazla olduğu bulundu $(* * \mathrm{P}<0.01)$.

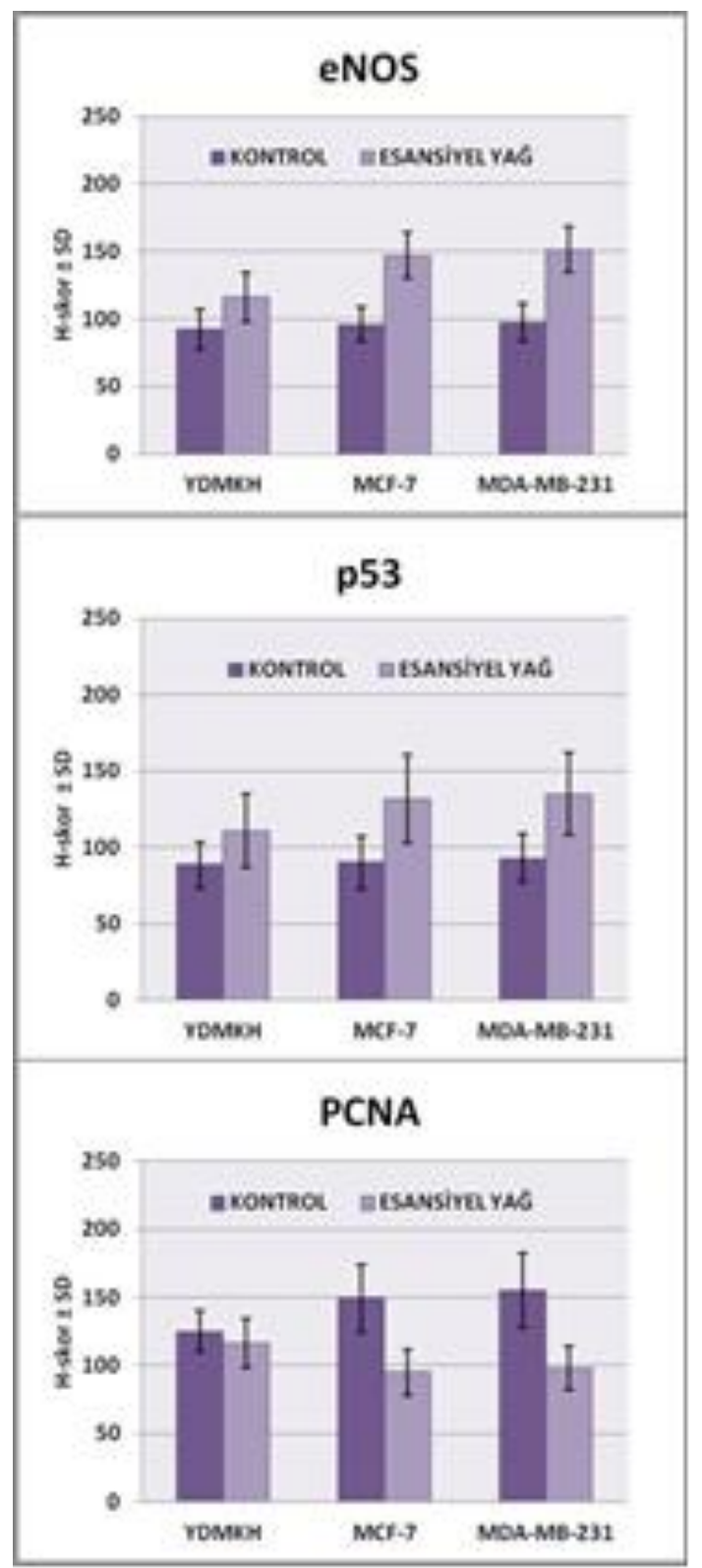

Şekil 1. Esansiyel yağ uygulaması sonrası hücrelerde eNOS, p53 ve PCNA immünositokimya boyanmalarının H-skor ile değerlendirilmesi.

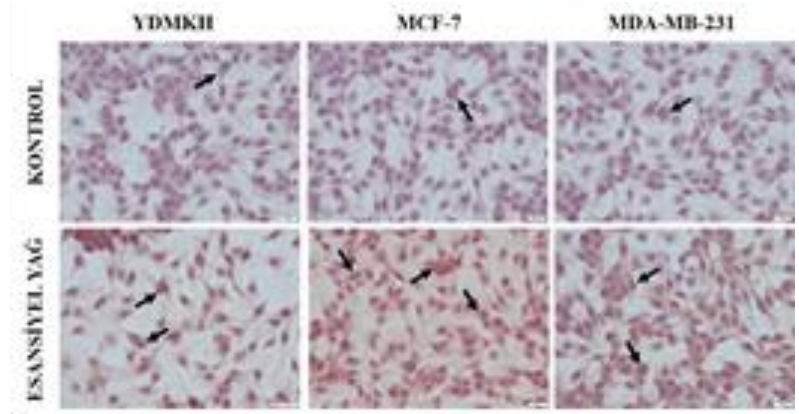

Şekil 2. Deney sonrasında hücrelerde eNOS dağılımı. Oklar: İmmünpozitif hücre, Barlar: $20 \mu \mathrm{m}$. 


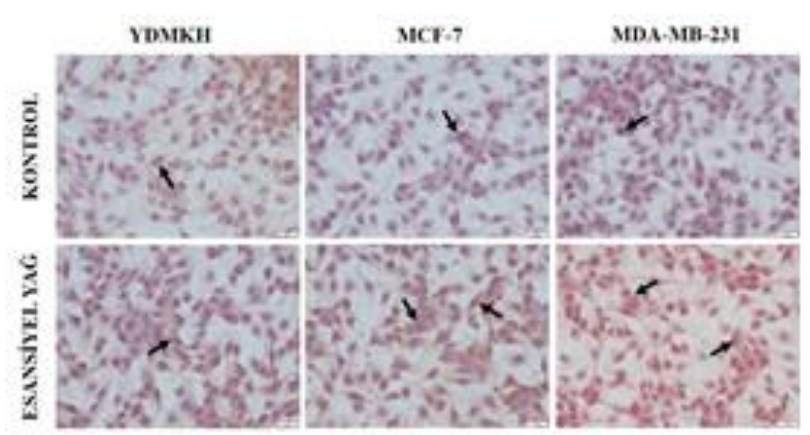

Şekil 3. Deney sonrasında hücrelerde p53 dağılımı. Oklar: İmmünpozitif hücre, Barlar: $20 \mu \mathrm{m}$.

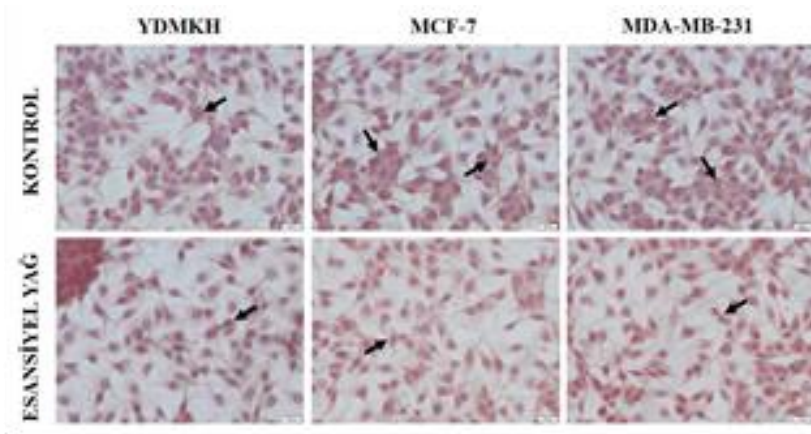

Şekil 4. Deney sonrasında hücrelerde PCNA dağılımı. Oklar: İmmünpozitif hücre, Barlar: $20 \mu \mathrm{m}$.

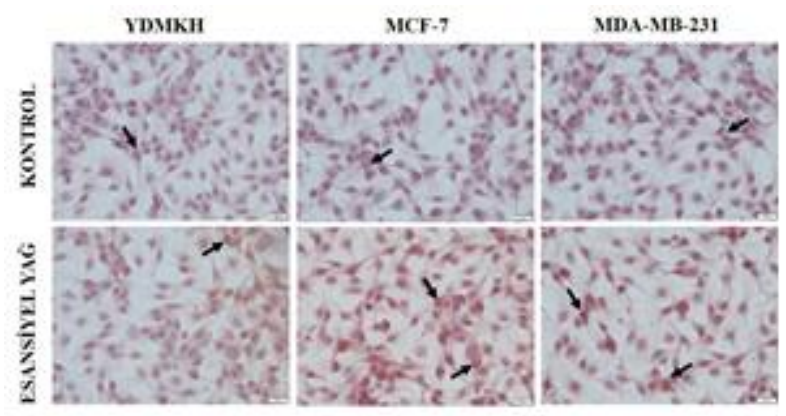

Şekil 5. Deney sonrasında apoptotik hücre dağılımı. Oklar: Apoptotik hücre, Barlar: $20 \mu \mathrm{m}$.

\begin{tabular}{ccc|}
\hline & KONTROL & ESANSIYEL YA $\bar{G}$ \\
YDMKH & $8,9 \pm 1,1$ & $10,1 \pm 1,2$ \\
MCF-7 & $10,6 \pm 1,1$ & $12,1 \pm 1,7$ \\
MDA-MB-231 & $9,1 \pm 1,3$ & $13,7 \pm 1,6$ \\
\hline
\end{tabular}

Şekil 6. Deney sonrasında hücre ölüm oranını gösteren apoptotik indeks.

\section{Tartışma}

İn vitro ve in vivo çalışmalarda meme kanserinde, sitotoksik etki ile birlikte antitümörojenik özellik gösteren birçok kemoterapötik ajan ve bitkisel ürünler kullanılmaktadır. $\mathrm{Bu}$ çalışmalar arasında bitkisel ürünlerin veya ekstraktların antikanserojen etkilerinin gösterilmesi, kanser tedavisinde destekleyici ajan olarak kullanımlarının önünü açacaktır [35-38]. Antikanser özelliği deneysel in vitro ve in vivo çalışmalarla kanıtlanmış bitkiler olmakla birlikte henüz biyolojik etkinliği tam olarak bilinmeyen bitkiler de bulunmaktadır. Kontrollü doz çalışması yapılmamış bitkisel ürünlerin kullanımı sonucu hastada olumsuz etkiler oluşabilmektedir [35-37]. Ballıbabagiller (Labiatae, Lamiaceae) familyasından olan Origanum minutiflorum O. Schwarz et. H. Davis türünün antikanser aktivitesi henüz belirlenmemiştir. Ancak bu familyaya ait Perovskiaabrotanoides Kar. Mesosphaerum sidifolium, Thymus caramanicus Jalas, Rosmarinus Officinalis L. gibi türlerin kanser hücreleri üzerindeki sitotoksik etkisi in vitro ve in vivo çalışmalarla gösterilmiştir [39-43].

Thymus caramanicus Jalas türünün esansiyel yağı ve etanolik ekstraktının sitotoksik etkileri KB oral karsinoma ve HGF1-PI1 gingiva fibroblast hücrelerinde çalışılmıştır. KB oral karsinoma hücreleri için esansiyel yağ IC50 dozunun $0.35 \mu \mathrm{L} / \mathrm{mL}$ ve etanolik ekstraktının IC50 dozunun ise $73.11 \mu \mathrm{g} / \mathrm{mL}$ olduğu, antiproliferatif etkileri MTT yöntemi ile bakıldığında, toksik etkinin KB oral karsinoma hücrelerinde fibroblast hücrelerine göre daha fazla olduğu bildirilmektedir [43]. Ehrlich asit tümör modeli oluşturulmuş dişi farelerde Mesosphaerum sidifolium'dan elde edilmiş esansiyel yağın ve bu yağ içerisindeki bileşenler izole edilerek in vivo antikanserojen etkisi incelendiğinde, tek başına etken madde uygulanmasından ziyade esansiyel yağı ayrıştırmadan kullanıldığında antitümör aktivitesinin daha yüksek olduğu saptanmıştır. Esansiyel yă̆ içeriğinde 57 bileşen bulunmakla birlikte en fazla fenkon (\% 24.8), cubebol (\%6.9), limonen (\%5.4), sipatulenol (\% 4.5), $\beta$-karyofilin (\%4.6) ve $\alpha$-kadinolden $(\% 4.7)$ oluşmaktadır. Esansiyel yağ ve sadece fenkon uygulamaları ayrı ayrı yapıldığında, esansiyel yă sitotoksik özelliğinin yüksek olmasının içeriğindeki \% 24.8 oranındaki fenkon varlığından kaynaklanabileceği düşünülmüştür.

Esansiyel yağın genotoksisitesi değerlendirildiğinde dişi fare kanındaki mikronukleuslu eritrosit sayısının kemoterapötik kanser ilaçlarına göre 1lımlı düzeyde olduğu dikkat çekmektedir [42].

Origanum minutiflorum O. Schwarz et. H. Davis türünden elde edilmiş sulu ve metanolik ekstraklarının sitotoksik etkisi sadece BHK21 böbrek fibroblast hücrelerinde incelenmiş olup in vivo veya in vitro antikanser etkisi hakkında yapılmış herhangi bir çalışma bulunmamaktadır.

BHK21 böbrek fibroblastları hücre dizini olmasına karşılık kanserojen özellikleri yok denecek düzeyde normal hücre karakterine sahiptir. Nitekim bitkinin sulu ve metanolik ekstraklar1 BHK21 hücrelerine $10 \mu \mathrm{L} / \mathrm{mL}$, $25 \mu \mathrm{L} / \mathrm{mL}, 50 \mu \mathrm{L} / \mathrm{mL}$ ve $100 \mu \mathrm{L} / \mathrm{mL}$ oranlarında verilerek MTT yöntemiyle analiz edildiğinde hiçbir toksik etki göstermediği saptanmıştır [44]. Bu tür ile yapılan çalışmalar daha çok antioksidan kapasitesinin ve bileşenlerinin belirlenmesine yönelik olup, antimikrobiyal ve akarisidal etki gösterdiği 
bildirilmektedir $\quad$ [44,45-50].Bizim çalışmamızda kullandığımız oregano esansiyel yağı da Origanum minutiflorum O. Schwarz et. H. Davis türünden elde ederek iki farklı meme kanser hücre dizini ve normal hücre olarak mezenkimal kök hücreler üzerindeki etkisini karşılaştırdığımızda mezenkimal kök hücre üzerinde belirgin bir sitotoksik aktivite göstermediği saptand1. Diğer yandan antitümör aktivitenin hem MCF7 hem de MDA-MB-231 meme kanser hücrelerinde oldukça artmış olduğu ve hücre çoğalmasının baskılandığ1 belirlendi. $\mathrm{Bu}$ antikanser aktivitenin apoptoz aracılığ ile meydana geldiği p53 belirtecinin ve apoptotik hücre sayısının artması ve hücre çoğalma belirteci PCNA'nın azalması ile sonuçlandığı görüldü. Ancak, oregano yağının antikanser aktivitesinin, yapılacak detaylı ve moleküler gerek in vitro gerekse in vivo çalışmalarla desteklemesi gerekmektedir.

\section{Sonuc}

Günümüzde kanser teşhisinde geç kalınabilmekte ve tedavisinde cerrahi ve kemoterapi yetersiz olabilmektedir. Bu nedenle son yıllarda klasik tedaviye destekleyici faktör veya ajanların klinik uygulamalar arasında yer alması konusunda çalışmalar devam etmektedir. Bitkisel ürünlerin kullanımı bunlardan biri olup halk arasında yaygın bir rağbet gören durumdur. Fakat bitkilerin yapılan çalışmalarda tedavideki etkinliği belirlenmeden yapıldığında hasta açısından olumsuz bir etki yaratabilmektedir. $\mathrm{Bu}$ nedenle kullanılacak bitki veya ürünün tedavi edebilir etkinliğinin deneysel olarak kanıtlanmış olması gerekmektedir.

Çalışmamızda; Origanum minutiflorum O. Schwarz et. H. Davis türünden edilen esansiyel yağın antikanser özelliği sahip olduğunu belirlendi. Ancak bitkisel ürün olarak kullanılabilmesi için moleküler teknikler kullanılarak spesifik in vivo çalışmalarla birlikte bu yağ içeriğinde bulunan bileşenlerin belirlenmesine yönelik çalışmalara ihtiyaç olduğu sonucuna varıldı.

\section{Bilgilendirme}

$\mathrm{Bu}$ çalışma; "The 2nd International Conference on Natural Products for Cancer Prevention and Therapy" kongresinde sözlü olarak sunulmuştur.

\section{Referanslar}

1. Perumalsamya, H, Sankarapandian, K, Kandaswamy, N, Balusamy, S.R, Periyathambi, D, Raveendiran, N, Cellular effect of styrene substituted biscoumarin caused cellular apoptosis and cell cycle arrest in human breast cancer cells. Int J Biochem Cell B, 2017, 92:104-14.

2. Costa Araldi, I.C, Bordin, F.P.R, Cadoná, F.C, Barbisan, F, Azzolin, V.F, Teixeira, C.F, Baumhardt, T, Cruz, I.B.M, Duarte, M.M.M.F, Bauermann, L.F, The in vitro radiosensitizer potential of resveratrol on $\mathrm{MCF}-7$ breast cancer cells. Chem-Biol Interact, 2018, DOI: 10.1016/j.cbi.2018.01.013.

3. Saueressig, S, Tessmann, J, Mastelari, R, Pereira da Silva, L, Buss, J, Segatto, N.V, Begnini, K.R, Pacheco, B, Pereira de Pereira, C.M, Collares, T, Seixas, F.K, Synergistic effect of pyrazoles derivatives and doxorubicin in claudin-low breast cancer subtype. Biomed Pharmacother, 2018, 98: 390-8.

4. Park, E.J, Lee, D, Baek, S.E, Kim, K.H, Kang, K.S, Jang, T.S, Lee, H.L, Song, J.H, Yoo, J.E, Cytotoxic effect of sanguiin
H-6 on MCF-7 and MDA-MB-231 human breast carcinoma cells. Bioorg Med Chem Lett, 2017, 27: 4389-92.

5. Subash-Babu, P, Li, D.K, Alshatwi, A.A, In vitro cytotoxic potential of friedelin in human MCF-7 breast cancer cell: Regulate early expression of Cdkn2a and $\mathrm{pRb} 1$, neutralize mdm2-p53 amalgamation and functional stabilization of p53. Exp Toxicol Pathol, 2017, 69: 630-6.

6. Zarei, O, Yaghoobi, M.M, Cytotoxic effects of Fritillaria imperialis L. extracts on human liver cancer cells, breast cancer cells and fibroblast-like cells. Biomed Pharmacother, 2017, 94: 598-604.

7. Kumari, S, Badana, A.K, Mohan, G.M, Naik, G.S, Malla, R.R, Synergistic effects of coralyne and paclitaxel on cell migration and proliferation of breast cancer cells lines. Biomed Pharmacother, 2017, 91: 436-45.

8. Maryam, R, Faegheh, S, Majid, A.S, Kazem, N.K, Effect of quercetin on secretion and gene expression of leptin in breast cancer. J Tradit Chin Med, 2017, 37(3): 321-5.

9. Wang, G, Li, J, Zhang, L, Huang, S, Zhao, X, Zhao, X, Celecoxib induced apoptosis against different breast cancer cell lines by down-regulated NF- $\mathrm{B}$ pathway. Biochem Biophys Res Commun, 2017, pii: S0006-291X(17)31279-2. doi:10.1016/j.bbrc.2017.06.148.

10. Wang, X, Liu, X, Li, Y, Wang, P, Feng, X, Liu, Q, Yan, F, Zheng, $H$, Sensitivity to antitubulin chemotherapeutics is potentiated by a photoactivable nanoliposome. Biomaterials, 2017, 141:50-62. doi: 10.1016/j.biomaterials.2017.06.034.

11. de Oliveira Mauro, M, Matuo, R, de David, N, Strapasson, R.L.B, Oliveira, R.J, Stefanello, M.É.A, Kassuya, C.A.L, de Cepa Matos, M.F, Faria, F.J.C, Costa, D.S, Actions of sesquiterpene lactones isolated from Moquiniastrum polymorphum subsp. Floccosum in MCF7 cell line and their potentiating action on doxorubicin. BMC Pharmacol Toxicol, 2017, 18(1):53. doi: 10.1186/s40360-017-0156-3.

12. Li, J, Yao, Q.Y, Xue, J.S, Wang, L.J, Yuan, Y, Tian, X.Y, Su, H, Wang, S.Y, Chen, W.J, Lu, W, Zhou, T.Y, Dopamine D2 receptor antagonist sulpiride enhances dexamethasone responses in the treatment of drug-resistant and metastatic breast cancer. Acta Pharmacol Sin, 2017, doi: 10.1038/aps.2017.24.

13. Yao, M, Yuan, B, Wang, X, Sato, A, Sakuma, K, Kaneko, K, Komuro, H, Okazaki, A, Hayashi, H, Toyoda, H, Pei, X, Hu, $\mathrm{X}$, Hirano, T, Takagi, N, Synergistic cytotoxic effects of arsenite and tetrandrine in human breast cancer cell line MCF7. Int J Oncol, 2017, doi: 10.3892/ijo.2017.4052.

14. Liu, Y, Wang, R, Zhang, L, Li, J, Lou, K, Shi, B, The lipid metabolism gene FTO influences breast cancer cell energy metabolism via the PI3K/AKT signaling pathway. Oncol Lett, 2017, 13(6):4685-4690. doi: 10.3892/ol.2017.6038.

15. Chen, S, Meng, T, Zheng, X, Cai, J, Zhang, W, You, H, Xing, J, Dong, Y, Contribution of nucleophosmin overexpression to multidrug resistance in breast carcinoma. J Drug Target, 2017, 1-9. doi: 10.1080/1061186X.2017.1332066.

16. Chun, S.Y, Kim, S, Nam, K.S, The inhibitory effects of deepsea water on doxorubicin induced epithelial-mesenchymal transition. Oncol Rep, 2017, doi: 10.3892/or.2017.5726.

17. Panjehpour, M, Castro, M, Klotz, K.N, Human breast cancer cell line MDA-MB-231 expresses endogenous A2B adenosine receptors mediating a $\mathrm{Ca} 2+$ signal. $\mathrm{Br} \mathrm{J}$ Pharmacol, 2005, 145(2):211-8.

18. Elamin, M.H, Elmahi, A.B, Daghestani, M.H, Al-Olayan, E.M, Al-Ajmi, R.A, Alkhuriji, A.F, Hamed, S.S, Elkhadragy, M.F, Synergistic Anti-Breast-Cancer Effects of Combined Treatment With Oleuropein and Doxorubicin In Vivo. Altern Ther Health Med, 2017, pii: AT5644.

19. Lokerse, W.J.M, Bolkestein, M, Dalm, S.U, Eggermont, A.M.M, de Jong, M, Grüll, H, Koning, G.A, Comparing the therapeutic potential of thermosensitive liposomes and hyperthermia in two distinct subtypes of breast cancer. J Control Release, 2017, 258:34-42. doi: 10.1016/j.jconrel.2017.05.005

20. Brito, L.C, Berenger, A.L.R, Figueiredo, M.R, An overview of anticancer activity of Garcinia and Hypericum. Food Chem Toxicol, 2017, 109: 847-62.

21. Hajlaoui, H, Mighri, H, Aouni, M, Gharsallah, N, Kadri, A, Chemical composition and in vitro evaluation of antioxidant, 
antimicrobial, cytotoxicity and anti- acetylcholinesterase properties of Tunisian Origanum majorana L. essential oil. Microb Pathog, 2016, 95: 86-94.

22. Bouyahya, A, Bakri, Y, Et-Touys, A, Assemian, I.C.C, Abrini, $\mathrm{J}$, Dakka, N, In vitro antiproliferative activity of selected medicinal plants from the North-West of Morocco on several cancer cell lines. Eur J Integr Med, 2018, 18: 23-9.

23. Bostancioğlu, R.B, Kurkcuoğlu, M, Başer, K.H.C, Koparal, A.T, Assessment of anti-angiogenic and anti-tumoral potentials of Origanum onites L. essential oil. Food Chem Toxicol, 2012, 50: 2002-8.

24. Han, X, Parker, T.L, Anti-inflammatory, tissue remodeling, immunomodulatory, and anticancer activities of oregano (Origanum vulgare) essential oil in a human skin disease model. Biochim Open, 2017, 4: 73-7.

25. Abdel-Massih, R.M, Fares, R, Bazzi, S, El-Chami, N, Baydoun, E, The apoptotic and anti-proliferative activity of Origanum majorana extracts on human leukemic cell line. Leuk Res, 2010, 34: 1052-6.

26. Al-Kalaldeh, J.Z, Abu-Dahab, R, Afifi, F.U, Volatile oil composition and antiproliferative activity of Laurus nobilis, Origanum syriacum, Origanum vulgare, and Salvia triloba against human breast adenocarcinoma cells. Nutr Res, 2010 30: 271-8.

27. Baydar, H, Yayla kekiği (origanum minutiflorum o. schwarz et. p. h. davis)'nde farklı toplama zamanlarının uçucu yağ içeriği ve uçucu yağ bileşenleri üzerine etkisi. Mediterr Agric Sci, 2005, 18(2): 175-8

28. Tuğlu, M.İ, Özdal-Kurt, F, Koca, H, Sarac, A, Barut, T, Kazanç, A, The Contribution of Differentiated Bone Marrow Stromal Stem CellLoaded Biomaterial to Treatment in Critical Size Defect Model in Rats. Kafkas Univ Vet Fak Derg, 2010, 16 (5): 783-92.

29. Uluer, E.T, Aydemir, I, Inan, S, Ozbilgin, K, Vatansever, H.S, Effects of 5-fluorouracil and gemcitabine on a breast cancer cell line (MCF-7) via the JAK/STAT pathway. Acta Histochem, 2012, 114(7): 641-6.

30. Deliloglu, G.I, Tuglu, I, Vatansever, H.S, Ozdal-Kurt, F, Ekren, H, Taylan, M, Sen, B.H, The effect of osteogenic medium on the adhesion of rat bone marrow stromal cell to the hydroxyapatite. Saudi Med J, 2006, 27(3): 305-11.

31. Kurt, F.Ö, Tuğlu, I, Vatansever, H.S, Tong, S, Şen, B.H, Deliloğlu-Gürhan, S.I, The effect of different implant biomaterials on the behavior of canine bone marrow stromal cells during their differentiation into osteoblasts. Biotech Histochem, 2016, 91(6): 412-22.

32. Karabuga, I, Akbay, K, Turna, B, Vatansever, H.S, Altay, B, Güzel, E, Turkoz-Uluer, E, Ustun, G, Ekren, F, Nazli, O, Muftuoglu, S, Apaydin, E, Effect of lisinopril on renal tissue damage in unilateral ureteral obstruction in rats. Urol Res, 2012, 40(1): 27-34

33. Gürpınar, T, Ekerbiçer, N, Uysal, N, Barut, T, Tarakçı, F, Tuglu, M.I, The effects of the melatonin treatment on the oxidative stress and apoptosis in diabetic eye and brain. Scientific World Journal, 2012, 2012:498489.

34. Ozbilgin, K, Karaca, F, Turan, A, Köse, C, Vatansever, S, Ozcakir, T, The higher heparin-binding epidermal growth factor (HB-EGF) in missed abortion. Taiwan $\mathrm{J}$ Obstet Gynecol, 2015, 54(1): 13-8

35. Hack, C.C, Voiß, P, Lange, S, Paul, A.E, Conrad, S, Dobos, G.J, Beckmann, M.W, Kümmel, S, Local and Systemic Therapies for Breast Cancer Patients: Reducing Short-term Symptoms with the Methods of Integrative Medicine Geburtshilfe Frauenheilkd, 2015, 75(7): 675-82.

36. Kim, W, Lee, W.B, Lee, J.W, Min, B.I, Baek, S.K, Lee, H.S, Cho, S.H, Traditional herbal medicine as adjunctive therapy for breast cancer: A systematic review. Complement Ther Med, 2015, 23(4): 626-32.

37. Zheng, J, Zhou, Y, Li, Y, Xu, D.P, Li, S, Li, H.B, Spices for Prevention and Treatment of Cancers. Nutrients, 2016, 8(8): E495.
38. Tariq, A, Sadia, S, Pan, K, Ullah, I, Mussarat, S, Sun, F, Abiodun, O.O, Batbaatar, A, Li, Z, Song, D, Xiong, Q, Ullah, R, Khan, S, Basnet, B.B, Kumar, B, Islam, R, Adnan, M, A systematic review on ethnomedicines of anti-cancer plants. Phytother Res, 2017, 31(2): 202-64.

39. Moore, J, Yousef, M, Tsiani, E, Anticancer Effects of Rosemary (Rosmarinus officinalis L.) Extract and Rosemary Extract Polyphenols. Nutrients, 2016, 8(11): E731.

40. Santos, P.A, Avanço, G.B, Nerilo, S.B, Marcelino, R.I, Janeiro, V, Valadares, M.C, Machinski, M, Assessment of Cytotoxic Activity of Rosemary (Rosmarinus officinalis L.), Turmeric (Curcuma longa L.), and Ginger (Zingiber officinale R.) Essential Oils in Cervical Cancer Cells (HeLa). Scientific World Journal, 2016, 2016:9273078.

41. Zaker, A, Asili, J, Abrishamchi, P, Tayarani-Najaran, Z, Mousavi, S.H, Cytotoxic and apoptotic effects of root extract and tanshinones isolated from Perovskiaabrotanoides Kar. Iran J Basic Med Sci, 2017, 20(12): 1377-84.

42. Rolim, T.L, Meireles, D.R.P, Batista, T.M, de Sousa, T.K.G, Mangueira, V.M, de Abrantes, R.A, Pita, J.C.L.R, Xavier, A.L, Costa, V.C.O, Batista, L.M, da Silva, M.S, Sobral, M.V, Toxicity and antitumor potential of Mesosphaerum sidifolium (Lamiaceae) oil and fenchone, its major component. BMC Complement Altern Med, 2017, 17(1):347.

43. Fekrazad, R, Afzali, M, Pasban-Aliabadi, H, Esmaeili-Mahani, S, Aminizadeh, M, Mostafavi, A, Cytotoxic Effect of Thymus caramanicus Jalas on Human Oral Epidermoid Carcinoma KB Cells. Braz Dent J, 2017, 28(1): 72-7.

44. Oke, F, Aslim, B, Biological potentials and cytotoxicity of various extracts from endemic Origanum minutiflorum $\mathrm{O}$. Schwarz \& P.H. Davis. Food Chem Toxicol, 2010, 48(6): 1728-33.

45. Dadalioglu, I, Evrendilek, G.A, Chemical compositions and antibacterial effects of essential oils of Turkish oregano (Origanum minutiflorum), bay laurel (Laurus nobilis), Spanish lavender (Lavandula stoechas L.), and fennel (Foeniculum vulgare) on common foodborne pathogens. J Agric Food Chem, 2004, 52(26): 8255-60.

46. Dorman, H.J, Bachmayer, O, Kosar, M, Hiltunen, R, Antioxidant properties of aqueous extracts from selected lamiaceae species grown in Turkey. J Agric Food Chem, 2004, 52(4): 762-70.

47. Cetin, H, Yanikoglu, A, A study of the larvicidal activity of Origanum (Labiatae) species from southwest Turkey. J Vector Ecol, 2006, 31(1): 118-22.

48. Cetin, H, Cilek, J.E, Aydin, L, Yanikoglu, A, Acaricida effects of the essential oil of Origanum minutiflorum (Lamiaceae) against Rhipicephalus turanicus (Acari: Ixodidae). Vet Parasitol, 2009, 160 (3-4):359-61.

49. Süntar, I, Akkol, E.K, Keleş, H, Oktem, A, Başer, K.H, Yesilada, E, A novel wound healing ointment: a formulation of Hypericum perforatum oil and sage and oregano essential oils based on traditional Turkish knowledge. J Ethnopharmacol, 2011, 134(1): 89-96.

50. Akdemir Evrendilek, G, Empirical prediction and validation of antibacterial inhibitory effects of various plant essential oils on common pathogenic bacteria. Int J Food Microbiol, 2015, 202: $35-41$.

http://edergi.cbu.edu.tr/ojs/index.php/cbusbed isimli yazarın CBU-SBED başlıklı eseri bu Creative Commons Alınt1-Gayriticari4.0 Uluslararas1 Lisansı ile lisanslanmıştır.

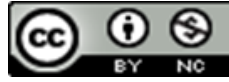

